\title{
Council Court's Judgement in the Decision of Sued for Divorce Husband at the Tapaktuan Syar'iyah Court
}

\author{
Riza Nazlianto \\ STAI Tapaktuan \\ mardhatillah.atjeh@gmail.com
}

\begin{abstract}
Shari'ah gives the wife the right to complain to the judge gives thalaq to him, even the Shari'ah also requires the judge to grant his wish iffound causes that push to gives thalaq to in accordance with what is desired by the wife, while the husband does not want to divorce his wife good road. The aim of this research is to know the divorce case in society Tapaktuan. In compiling this thesis of researchers use qualitative research methods.
\end{abstract}

Keywords : Divorce: Shari'ah Court; Article of marriage

\section{Introduction}

Every human being must aspire so that his marriage can last forever, and does not want to be cut off in the middle of the road. But sometimes, a marriage by certain causes can result in being unable to continue so it must be decided in the middle of the road or forced to break up on its own. The reality of human life proves that there are factors that encourage disharmony in the household. Many things can tear down the household ark so trying to defend it is something that is in vain. If the household cannot be maintained, and if it maintains it, it will lead to prolonged disputes and suffering, Islam will not tie the death of marriage but it will not facilitate divorce.

The last alternative taken if peace is not successful is divorce. "Discontinuation of marriage" is a legal term used in the marriage law to explain divorce or the end of a marriage relationship between a man and a woman who has lived as a husband and wife. The breakup of marriage is when the initiative of the husband is called thalaq and there is also an initiative from the wife called fasakh (divorce). As we know, that thalaq is the right of the husband, according to the meanings that have been explained in many discussions. On the other hand, the most wise God also cares for the benefit of his wife. therefore, God blessed the right to free himself by giving wealth if he hated her husband, and he realized that his life with her husband could not be balanced for both parties.

When this provision cannot eliminate all difficulties from the wife, either because sometimes the husband is not willing to accept ransom, or the wife is not able to give the ransom requested by the husband, as the wife feels from domestic life which is not limited to her hatred of her husband and sometimes other problems arose which prompted him to ask for divorce, the Shari'a opened the door of divorce to his wife, even though her husband did not let him go.

Shari'ah gives the wife the right to complain to the judge gives thalaq to him, even the Shari'ah also requires the judge to grant his wish if found causes that push to gives thalaq to in accordance with what is desired by the wife, while the husband does not want to divorce his wife good road. Divorce is a broken marriage bond as a result of a request submitted by the wife to a Religious Court which the respondent (husband) agrees to, so that the Religious Court grants the request.

Today, over time, in Indonesia there are several professions which require a husband to leave his wife and child to earn a living or carry out state duties for a long period of time. One of the worries of a wife is when a husband who leaves for a long time disappears without 
knowing the news and leaving his obligations as a husband. So as to cause birth and inner losses for wives and children left behind. A lost husband (mafqud / ghoib) will certainly cause new problems for the household. The loss of a husband will make a wife overwhelmed with a sense of uncertainty about the legal status she has. So that is not infrequently a wife decides to sue for divorce her husband who is not clear about the news.

A wife can submit a divorce claim to Syar'iyah Court if her husband has disappeared and the news is not known for 2 two years or more. But the reality that we met at the Tapaktuan Syar'iyah Court was that there were several cases which by the panel of judges ruled that the divorce case was sued because the husband had mafqud before up to two years.

\section{Literature Review}

\subsection{Definition of Divorce}

Based on the conception of marriage according to Article 1 paragraph (1) of Law Number 1 of 1974 concerning Marriage that what is meant by marriage is a physical and spiritual bond between a man and a woman as husband and wife to form a happy family and family. Articles about marriage are truly hard happened divorce. The main point of household life is calm, tranquility and continuity. Islam regulates this relationship with all its safeguards which ensure peace and continuity so that it reaches a high level of obedience. The Marriage Law basically complicates divorce. The reason for forming a law makes it difficult for divorce to be:

a. Marriage has a sacred and noble purpose, while divorce is an act that is hated by God;

b. To limit the arbitrariness of a husband to a wife; and

c. To raise the degree and dignity of the wife (woman) so that it is in line with the degree and dignity of the husband (male).

Although marriage is a despicable act and is hated by God, husband and wife may divorce if their marriage cannot be maintained anymore. However, divorce must have reasons such as those regulated by the Law that between husband and wife will not be able to live in harmony as husband and wife. The issue of termination of marriage or divorce and its consequences, is regulated in Article 38 to Article 41 of the Marriage Law.

Article 38 Marriage Law:
a. Dead;
b. Divorce;
c. For the Court's decision.

What is meant by the termination of marriage due to death is the end of marriage due to one party, husband or wife dying. While divorce is the abolition of marriage between a judge's decision or the demands of one of both in marriage. The breakup of marriage due to divorce can occur due to two things, namely: (1)thalaq, or (2) based on a divorce suit. The breakup of marriage because of a court ruling is the end of marriage based on court decisions that have obtained permanent legal force.

Article 39 of the Marriage Law: 
a. Divorce can only be carried out before a court hearing after the court concerned has tried and has not succeeded in reconciling the two parties;

b. For divorce there must be enough reason, that between husband and wife will not be able to live in harmony as husband and wife;

c. The procedure for divorce in front of a court session is regulated in its own laws and regulations.

Article 40 of the Marriage Law:

a. A divorce lawsuit is submitted to the court;

b. The procedure for filing a claim in paragraph (1) of this article is regulated in separate laws and regulations.

Divorce is regulated in Article 73 of the Law on Religious Courts as follows:

Article 73 of the Law on Religious Courts:

a. The divorce lawsuit is submitted by the wife or her attorney to the Court whose legal area covers the plaintiff's residence, except if the plaintiff intentionally leaves the residence together without the defendant's permission;

b. In the case of the plaintiff's residence in a foreign country, the divorce suit shall be made to the court whose legal territory covers the residence of the defendant;

c. In the case of the plaintiff and the defendant residing abroad, the claim is filed with a court whose legal territory includes their marriage or at the Central Jakarta Religious Court.

\subsection{Divorce in Fiqh Perspective}

\section{Definition of Divorce} follows:

Related the marriage, Allah SWT said it in (Q.S. An-Nisa ': 21) which reads as

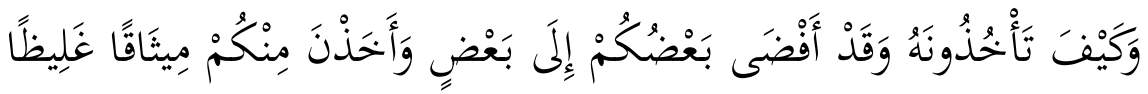

Meaning: How can you take it away after each one has enjoyed the other, and they have taken a firm covenant from you?

Allah calls the marriage bond in the Qur'an the An-Nisa 'verse 21 as mitsaqan ghalidhan (a very strong agreement). And hence, any attempt to underestimate the sacred bond or weaken it, let alone decide it is very hated by religion. Every human being must aspire so that his marriage can last forever, and does not want to be cut off in the middle of the road. But sometimes, a marriage by certain causes can result in being unable to continue so it must be decided in the middle of the road or forced to break up on its own. The reality of human life proves that there are factors that encourage disharmony in the household. Many things can tear down the household ark so trying to defend it is something that is in vain. If the household cannot be maintained, and if it maintains it, it will lead to prolonged disputes and suffering, Islam will not tie the death of marriage but it will not facilitate divorce. 
The last alternative taken if peace is not successful is divorce. "Breaking of marriage" is a legal term used in the marriage law to explain divorce or the end of a marriage relationship between a man and a woman who has lived as a husband and wife. The breakup of marriage is when the initiative of the husband is called thalaq and there is also an initiative from the wife called fasakh (divorce). As we know, that thalaq is the right of the husband, according to the meanings that have been explained in many discussions. Husbands drop it directly or represent it to others with representation or mastery. On the other hand, the most wise God also cares for the benefit of his wife. Therefore, God blessed the right to free himself by giving wealth if he hated her husband, and he realized that his life with her husband could not be balanced for both parties.

When this provision cannot eliminate all difficulties from the wife, either because sometimes the husband is not willing to accept ransom, or the wife is not able to give the ransom requested by the husband, as the wife feels from domestic life which is not limited to her hatred of her husband and sometimes other problems arose which prompted him to ask for divorce, the Shari'a opened the door of divorce to his wife, even though her husband did not let him go. Shari'ah gives the wife the right to complain to the judge to drop him, even the Shari'ah also requires the judge to grant his wish if found causes that push to drop thalaq in accordance with what is desired by the wife, while the husband does not want to divorce his wife good road.

\section{Methodology}

To find out an explanation of everything that is related to the subject matter, a research guideline called research methodology is needed, as a method used to search, formulate and analyze until compiling a thesis in order to achieve one goal. In compiling this thesis researchers use qualitative research methods. Qualitative research is research aimed at describing and analyzing phenomena, events, social activities, attitudes, beliefs, perceptions, and thoughts of individuals as well as in groups. Qualitative research is inductive, meaning that researchers let problems arise from the data or are left open to interpretation. The data of the researcher collects with careful observation, including descriptions in detailed contexts along with notes on the results of in-depth interviews, as well as analysis of documents and records.

The research approach that researchers use here is interactive qualitative research. Interactive qualitative research is an in-depth study using data collection techniques directly from subjects in their natural environment. The basic character in this research approach is a case study. Case studies (case studies) are research on "unitary systems". This unit can be in the form of programs, activities, events, or groups of individuals related to a particular place, time or bond. Case study is research that is directed at collecting data, gathering meaning, and gaining an understanding of the case. Case studies can consist of one or more units, but are one unit. The case can be one person, one class, one school, several schools but in one subdistrict office, and so on.

In this case study study, the case that lift researchers must really have problems that must be solved by the reader. In addition to displaying problems and information that can be used towards solutions to problems, the case that the researcher raises must also tell honestly, 
as is, without any elements of manipulation or engineering, and the researcher is able to give mental images of the cases presented.

Research on the Basics of Judges' Consideration of Divorced Decisions Because Mafqud's Husband at the Syar'iyah Tapaktuan Court, was held at the office of the Tapaktuan Syar'iyah Court in South Aceh district. The research activities started since the ratification of the research proposal and research permit, namely on April 6, 2017 until April 20, 2017.

\section{Discussion}

The process of resolving divorce cases because the husband mafqud at the Syar'iyah Tapaktuan court or the process of proceedings at Syar'iyah court is actually the same as the divorce process in general except for a number of special cases. This provision can be seen in Article 54 of Law Number 7 of 1989 concerning Religious Courts as amended by Law Number 3 of 2006 and the second amendment to Law Number 50 of 2009 which states that: "Procedure Law that applies to the Court in the Religion Court environment is the Civil Procedure Law which applies to Courts in the General Justice environment, except those specifically regulated in the Law."

Based on data from interviews conducted by the writer with the Judge at the Syar'iyah Court in Tapaktuan, data were obtained that the process of resolving the husband's divorce case had a slight difference with the settlement of divorce cases with other reasons, namely in the process of summoning the parties. The legal basis used by the Tapaktuan Syar'iyah Court is related to the calling in the divorce case of a husband and mafqud. If the residence of the summoned party is unknown or does not have a clear residence in Indonesia, then the call is made through the local Regent / Mayor by attaching summons on the Mahkamah Syar'iyah announcement board. The summons in the marriage case, the defendant is not known where he lives (unseen) is carried out:

First, Article 390 paragraph (3) HIR which states that:

Regarding people who do not know the place of residence or place of residence and about an unknown person, then the letter of the Savior is delivered to the Regent, in which the place of residence of the person who is indicted, and in the criminal case, is entitled to the Judge. The regent declared the Savior's letter by attaching it to the main door at the place of trial of the entitled Judge.

Second, Article 26 up to Article 27 of Government Regulation Number 9 of 1975 also regulates the procedure for calling the parties as follows:

\section{Article 26}

1. Each time a court hears a divorce lawsuit, both the plaintiff and the defendant or their attorney will be called to attend the hearing;

2. The court is delivered to the person concerned, if the person concerned cannot be found, the call is conveyed through lurah or the equivalent;

3. The summons as meant in paragraph (1) is carried out and delivered appropriately and has been received by the Plaintiff and the Defendant or their attorney no later than 3 (three) days before the trial is opened;

4. A call to the defendant is accompanied by a copy of the claim. 


\section{Article 27}

1. If the defendant is in a situation such as in Article 20 paragraph (2), the call is made by attaching a claim on the bulletin board in the Court and announcing it through one or several newspapers or other mass media determined by the Court;

2. Announcement through newspapers or newspapers or mass media paragraph (1) is carried out 2 (two) times with a one month grace period between the first and second announcements;

3. The deadline between the last call as referred to in paragraph (2) and the trial is set at least 3 (three) months;

4. In the event that a summons as referred to in paragraph (2) has been made and the defendant or proxy remains absent, the claim is accepted without the presence of the defendant, except if the claim is without rights or unreasonable.

Third, Article 138 up to Article 139 paragraph (1) to paragraph (4) Compilation of Islamic Law (KHI) which reads as follows:

\section{Article 138}

1. Every time a meeting of the Religious Courts is held which checks the divorce lawsuit, both the Plaintiff and the Defendant, or their power of attorney will be called to attend the hearing;

2. A call to attend a hearing as referred to in paragraph (1) is carried out by an officer appointed by the head of the Religious Court;

3. The call is sent to the person concerned. If the relevant person cannot be found, the call is delivered through the Lurah or equivalent;

4. The summons as referred to in paragraph (1) shall be carried out and delivered appropriately and received by the plaintiff and the defendant or their attorney no later than 3 (three) days before the trial is opened;

5. A call to the defendant shall be accompanied by a copy of the claim.

\section{Article 139}

1. If the residence of the defendant is unclear or the defendant does not have a permanent residence, the call is made by attaching a claim on the bulletin board in the Religious Court and announcing it through one or several newspapers or other mass media determined by the Religious Court;

2. Announcements through newspapers or newspapers or mass media paragraph (1) is done twice with a one-month grace period, between the first and second announcements;

3. The deadline between the last call referred to in paragraph (2) and the trial is set at least three months;

4. In the event that it has been carried out as referred to in paragraph (2) and the defendant or his proxy remains absent, the claim is accepted without the presence of the defendant unless the claim is without rights or unreasonable. 
Analysis of Decision No.0205 / Pdt.G / 2016, No.0220 / Pdt.G / 2015 and No.0230 / Pdt.G / 2015 at the Syar'iyah Tapaktuan court

In this sub-section the author will present the decision of the divorce case sued due to the husband's mafqud set by Sakti'iyah Tapaktuan Court, this case was examined by Tapaktuan Syar'iyah Court which took the source of the Law on Marriage Law (UUP) No.1 1974, Government Regulation (PP) No.9 of 1975 and Law (Law) No.7 of 1989 Compilation of Islamic Law (KHI). Four rules are used by the Religious Courts throughout Indonesia. Divorce according to Islam is recognized as the final solution in dealing with domestic crisis. Although divorce is permissible, it violates the principles and goals of marriage to be biased and fails to build a household with logical consequences, if a divorce is not carried out, then a household becomes hell for both parties or for one of them. To make a divorce must be enough reason, that between husband and wife cannot live in harmony again as husband and wife.

The process of resolving the divorce case of Mafqud's husband at the Tapaktuan Syar'iyah Court is actually the same as the divorce process in general, except for a number of special cases. The process of resolving a husband's divorce case mafqud has a slight difference with the settlement of divorce cases for other reasons, namely in the process of summoning the parties. From some legal basis it can be concluded that the summon of the Defendant (mafqud's husband) is carried out in the following ways:

First, the Chief Judge of the Syar'iyah Court of Justice in Tapaktuan attached a claim letter or summons on the Tapaktuan Syar'iyah Court notice board. The two announced through several newspapers or mass media twice with a grace period of one month. The deadline between the last call and the trial is set at least three or four months.

Furthermore, based on decision number 0230 / Pdt.G / 2015 / MS.Ttn the author can conclude that as for the judge's consideration in deciding this case is because between husband and wife there are continual disputes and quarrels and it is no longer possible to live in the household. Disputes and arguments are caused because the Defendant is married to another woman without permission from the Plain. Defendant is often drunk and often abuses the Plaintiff. The Defendant has also left the Plaintiff without permission and the valid reason for more or less six months did not even send the news so that his address in Indonesia is no longer known. Even though the Defendant's departure has not been up to two years, the judge still decides on their marital ties because the judge refers to the reasons for the ongoing arguments and disputes between them.

Legal facts that I obtained from the results of interviews at the Tapaktuan Syar'iyah Court, namely the judge granted a claim for divorce on the grounds that the husband was mafqud even though less than two years as stated in Article 116 point (b) Compilation of Islamic Law (KHI) because the judge has considerations and or reasons that are sufficient to provide strong evidence as the reason for divorce. Actually the divorce process because the unseen husband of less than two years has not been said to be valid if this statement is based on Article 116 letter (b) Compilation of Islamic Law (KHI). However, the judge has his own discretion or ijtihad which focuses on the occurrence of disputes and disputes as explained in Article 116 letter (f) Compilation of Islamic Law (KHI), namely: Between husband and wife there are continual disputes and quarrels and no hope of living again in the household.

This article is a reason that is sufficiently used as strong evidence for divorce. So it can be concluded from the results of the analysis that the legal basis used by the judge in deciding 
the divorce case is contested because the husband of mafqud is in accordance with established regulations and no one feels harmed by either his wife or husband.

From three decisions above, the judge uses the legal basis in deciding divorce due to the husband of mafqud who focuses on the Plaintiff's household with the Defendant always having quarrels and disputes between them, therefore to avoid greater harm and suffering for the wife, so that The Panel of Judges argued that the Plaintiff's household and Defendant could no longer be maintained. Based on these matters in the above three decisions in accordance with the facts because the reason for divorce in the case is clear, namely continuous disputes and disputes, which is in accordance with Article 39 paragraph (2) of Law Number 1 Year 1974 jo. Article 19 letter (f) Government Regulation Number 9 of 1975 letter (f) Compilation of Islamic Law (KHI). This dispute and dispute was caused by one of them because the Defendant was not responsible for the economy, the Defendant was too jealous of the Plaintiff, the Defendant often acted harshly on the Plaintiff, the Defendant often drunk and left the Plaintiff without saying goodbye and had no known address. As we know that without a living and the responsibility of a husband it is impossible to maintain a wife well. And we also understand that the existence of a wife with a condition that is far from her husband for a long time in addition to her consistency in maintaining purity and glory is a problem that cannot be borne by human nature in general.

\section{Conclusion}

Sakti'iyah Judge Tapaktuan in deciding case No.0205 / Pdt.G / 2016 / MS.Ttn, No.0220 / Pdt.G / 2015 / MS.Ttn, and No.0230 / Pdt.G / 2015 / MS. Yes, it is in accordance with the Compilation of Islamic Law (KHI) even though the husband's mafqud is less than 2 years, because the judge has an accident which is stated in Article 116 letter (f ) Compilation of Islamic Law (KHI) as a means of understanding, which is not very developed, so as to avoid greater harm to the Plaintiff, the Panel of Judges believes that Plaintiff's household and Defendant have not can be maintained again.

As we know that the Maliki and Hambali schools are also argued, we were interested because the husband's decision was permissible, if the husband didn't last for a long time, even though the husband left the property to his wife to make a living. However, they differed on the husband's absence in the long run. The Hambali School determines its time for six months. It is based on information narrated from Umar about the woman who was hurt by her husband who disappeared in a battle. One night, Umar heard the woman complaining by humming two verses of Syair. Umar then asked his daughter Hafsa, about the time when a wife must be patient because of her husband's loss. Umar gave people six months in their battle. While the Maliki School determines it in favored opinions, according to them, the limit is one year.

\section{References}

Abdul Aziz Muhammad Azzam dan Abdul Wahhab Sayyed Hawas, Fiqh Munakahat, Jakarta: Amzah, tt.

Abdulkadir Muhammad, Hukum Perdata Indonesia, Bandung: PT Citra Aditya Bakti, 2011.

Abdul Majid Mahmud Mathlub, Panduan Hukum Keluarga sakinah, Surakarta : Era Intermedia, 2005.

Abdul Rahman Ghozali, Fiqh Munakahat, Jakarta : kencana, 2008. 
Amandemen Undang-undang Republik Indonesia Nomor 3 Tahun 2006, tentang Peradilan Agama, Jakarta : Sinar Grafika, 2006.

Amir Syarifuddin, Hukum Perkawinan Islam di Indonesia, Jakrta : kencana, 2011.

Beni Ahmad Saebani, Fiqh Mawaris, Bandung : pustaka Setia, 2009.

Beni Ahmad Saebani, Metode Penelitian, Bandung : CV Pustaka Setia, 2008.

Burhan Bungin, Penelitian Kualitatif, Jakarta: Kencana, 2011.

Departemen Agama RI, Al-quran Dengan Terjemahannya, Bandung : CV. Penerbit J-Art, 2005.

Imam ibnu Hajar Asqalani, Shahih-Dhaif bulughul maram terjemahan, Solo: Al-Qawam, 2013.

Keputusan MA-RI Nomor : KMA/070/SK/X/2004, tentang : Pelimpahan sebahagian kewenangan dari Peradilan Umum kepada Mahkamah Syar'iyah Provinsi Nanggroe Aceh Darussalam, on Oktober 6 ${ }^{\text {th }}, 2004$

M. Djunaidi Ghony dan Fauzan Almanshur, Metodologi Penelitian Kualitatif, Jogjakarta : AR-RUZZ MEDIA, 2013.

M. Fakhruzaini Fahmi, Perceraian Akibat Suami Ghaib (Analisis Putusan Nomor 1043/pdt.G/2014/PA/Bjm), (Skripsi : Institut Agama Islam Negeri (IAIN) Antasari, 2016

Salim HS, Pengantar Hukum Perdata Tertulis (BW), Jakarta : Sinar Grafika, 2006.

Tihami dan Sohari Sahrani, Fikih Munakahat, Jakarta : Raja Wali Pers, 2013.

Titik Triwulan Tutik, Pengantar Hukum Perdata di Indonesia, Jakarta: Prestasi Pustaka Publisher, 2006.

Undang-undang R.I. Nomor 1 Tahun 1974 tentang Perkawinan dan Kompilasi Hukum Islam, Bandung: Citra Umbara, 2013.

Widiansah, Putusan Hakim Tentang Suami Ghaib di Pengadilan Agama Pacitan (Studi Kritis Perspektif KHI), (Skripsi : Sekolah Tinggi Agama Islam Negri (STAIN) Ponorogo, 2014

Zainuddin Ali, Hukum Perdata Islam di Indonesia, Jakarta: Sinar Grafika, 2006. 